\title{
ROZRACHUNEK Z POLSKOŚCIAC. POSZUKIWANIE TOŻSAMOŚCI NARODOWEJ W TWÓRCZOŚCI WOJCIECHA SMARZOWSKIEGO
}

\author{
STRUGGLE FOR NATIONAL IDENTITY \\ IN WOJCIECH SMARZOWSKI'S CINEMA
}

\begin{abstract}
The essay discusses mental and political thoughts in Smarzowski's cinema and presents an analysis on Polish mentality, class differentiation and deconstruction of traditional symbols. The author begins his study by outlining three theories tied with political ideology of national identity. Next, he traces the struggle for national mentality in Smarzowski's movies and through an account of how characters of varying films unite in search of ethnic roots. The article concludes with a discussion on Smarzowski's thinking about collective memory.
\end{abstract}

Key words: national identity; political ideology; collective memory; Smarzowski's movies; Polish mentality; Polish cinema

\section{Streszczenie}

Esej analizuje myśl narodową zawartą w filmach Wojciecha Smarzowskiego. Autor na filmowych egzemplifikacjach interpretuje zagadnienia polskiej mentalności, zróżnicowania klasowego i dekonstrukcji tradycyjnych symboli. W eseju zaprezentowane zostają teorie związane z pojęciem tożsamości narodowej. Zastanawiając się nad komunikatem, jaki Smarzowski wysyła do widza, autor wyróżnia trzy kategorie: odbicia lustrzanego, narodowych gustów i pierwiastka etnicznego. Artykuł kończy się dyskusją na temat pamięci zbiorowej w twórczości Smarzowskiego.

Wyrazy kluczowe: tożsamość narodowa; ideologia polityczna; kino Smarzowskiego; polska mentalność; polskie kino

MARCIN RADOMSKI Instytut Sztuki PAN, Warszawa E-mail: marcin.radomski@gmail.com This work was supported by the author's own resources. No competing interests have been declared.

This is an Open Access article distributed under the terms of the Creative Commons Attribution 3.0 PL License (creativecommons.org/licenses/by/3.0/pl/), which permits redistribution, commercial and non-commercial, provided that the article is properly cited. (c) The Author(s) 2015.

Publisher: Institute of Slavic Studies, Polish Academy of Sciences [Wydawca: Instytut Slawistyki PAN] 

występuje w większości dzieł reżysera jako charakterystyczny element scenografii ub atrybut bohaterów. W Róży Tadeusz zastanawia się: „Po co siekiera?”. Róża uśmiecha się i odpowiada: "Nie wiem..., żeby zło zabić?". Słowa te stanowią wyjaśnienie i jednocześnie zaświadczają o osobliwym charakterze kina Smarzowskiego. Jeden z najzdolniejszych polskich reżyserów, twórca Wesela i Drogówki w swoich filmach niczym kat używa narzędzia zbrodni, aby zinterpretować polskie przywary. Dlatego też w dyskursie dotyczącym twórczości Smarzowskiego nietrudno doszukać się wątków odwołujących się do polskiej tożsamości. Esej stanowi próbę zdefiniowania podejścia reżysera do wzorców narodowych i definicji pojęcia tożsamości narodowej. Czy zatem, idąc dalej, Smarzowskiego można nazwać przedstawicielem twórczości narodowej?

Polska mitologia narodowa jest w filmach Smarzowskiego mocno zakorzeniona. Twórca postrzega świat wertykalnie i horyzontalnie. Analizuje go poprzez własne postrzeganie rzeczywistości, jak i przestrzeń mityczną, która wyznacza kierunek biegu historii. Smarzowski tworzy egzemplifikujące i wzorcowe modele zachowań narodowych, aby na ich podstawie skonstruować współczesną mitologię narodową. Narracja kolejnych dzieł przebiega podobnie poprzez zastosowanie tożsamego klucza emocjonalnego. Pierwsze minuty filmów nadają im charakter, prezentują axis mundi bohaterów. Filar, który miał dawać oparcie i być symbolem osi kosmicznej, okazuje się romantyczną ułudą. Ujawniają się pary przeciwieństw naturalnie występujących w dyskursie o mitologii narodowej. Rodzą się przyziemne opozycje pozbawione racjonalnego wyjaśnienia. Po pewnym czasie w widzu pojawia się poczucie zażenowania i wstydu. Finał opowieści filmowej jest brutalny, a szereg zrytualizowanych zachowań obnaża naturalne zachowania obywateli. Zastanawiając się nad komunikatem, jaki Smarzowski wysyła do widza, należy wyróżnić trzy kategorie: odbicia lustrzanego, narodowych gustów i pierwiastka etnicznego.

Tożsamość narodowa rozumiana jest jako część tożsamości społecznej opartej na poczuciu odrębności wobec innych narodów. Jak zauważa Andrew Higson: „Tożsamość dotyczy w tym rozumieniu doświadczenia przynależności do wspólnoty zanurzonej w tradycji, rytuałach, charakterystycznych trybach dyskursu" (Higson, 2008, s. 7). Jest efektem kulturalizacji, czyli wprowadzenia i wchodzenia w uniwersum kulturowe, o którym z kolei pisała Antonina Kłoskowska (Kłoskowska, 2007, ss. 21-22). Idąc za tezą Andersona, współcześnie definiuje się naród „przez wyodrębnienie wspólnoty wyobrażonej z solidnie umocowaną tożsamością i poczuciem przynależności w zdecydowanie odgraniczonej i geopolitycznej przestrzeni" (Kłoskowska, 2007, s. 7). Definicja ta opiera się na teoriach performatywnych i określać ją należy jako „wspólnotę kultury”. Według Higsona, przenosząc kategorię tożsamości narodowej w przestrzeń kina, „z jednej strony spogląda się do wewnątrz, proponując refleksję o samym narodzie, jako przeszłości, teraźniejszości i przyszłości, jego dziedzictwie kulturowym i rodzinnych tradycjach w znaczeniu wspólnej tożsamości i ciągłości. Z drugiej zaś kino narodowe wykracza spojrzeniem ponad te granice, podkreślając swoją odmienność wobec innych kinematografii, proklamując poczucie inności" (Kłoskowska, 2007, s. 10). Takie podejście afirmuje Tadeusz Lubelski, który w książce Historia kina polskiego zaznaczat:

Kino z jednej strony - dzięki swej iluzyjności - rejestruje codzienność, wygląd ludzi i przedmiotów, architekturę, obyczaj, modę, całą zmieniającą się ikonosferę, z drugiej zaś - poprzez swoje fabuły - potrafi odsłaniać korzenie narodowych mitologii. Ta jego szczególna natura sprawia, że znakomicie nadaje się ono do stawiania podobnych pytań (Lubelski, 2010, s. 11). 
Pierwsza kategoria dotyczy odbicia lustrzanego. Pojęcie to należy wiązać z psychoanalizą Jacques'a Lacana i dotyczy ono pojęć pamięci i przeszłości. Dziecko, a później dorosły konstruuje wyobrażeniowy konstrukt własnej osoby. Kategorię odbicia lustrzanego można zastosować również do wyobrażenia grupy lub społeczności (Lacan, 1996, s. 72). Antropolodzy twierdzą, że dziś lustro można traktować jako oko kamery. Przyglądamy się swojemu wizerunkowi lub obrazowi środowisk zawodowych, społecznych, które znamy z doświadczeń, historii lub mediów. W Drogówce bohaterami są policjanci, w Róży mieszkańcy Mazur doświadczający bolesnej, powojennej rzeczywistości, w Domu złym tragicznie potraktowany przez los zootechnik i rodzina Dziabasów, a w Weselu biesiadujący w rytm muzyki disco-polo „typowi Polacy”. Protagoniści pomimo transformacji ustrojowej nie zmienili swojego zachowania, wręcz nie wyobrażają sobie innej egzystencji. Szczególnie Drogówka i Wesele są demaskatorskie. Obnażają kulturę chłopską, z której wszyscy się wywodzimy. Smarzowski, nawiązując do Wesela Wyspiańskiego, ukazuje panoramę wiejskiego życia i wachlarz zachowań społeczeństwa. Drogówka to elementarz każdego policjanta rozpoczynającego karierę. Soczewka postaw kierowców wobec funkcjonariuszy i władzy wobec społeczeństwa. Zasadniczą właściwością kina narodowego - jak zaznacza Witold Mrozek - „wydaje się zatem umiejętność zwięzłego ujmowania dystynktywnych cech danej formacji kulturowej" (Mrozek, 2010, s. 323).

Smarzowski w Weselu odwiedza Polaków podczas rodzinnego święta. Stawia kamerę na środku sali i niczym w Weselu Wajdy nagrywa żywiołowy taniec. Folwarczne uniwersum obecne jest w każdej scenie filmu. Począwszy od prezentu dla pary młodej, czyli kradzionego auta i podróży poślubnej „na” Chorwację. Zabawa odbywa się w remizie, gdzie gospodarzami są sportretowani stereotypowo rodzice panny młodej. Matka zajmuje się kuchnią, ojciec liczy pieniądze, których jak się okazuje każdy chce więcej niż się spodziewano. Duma prawdziwego Polaka nie pozwala mu kierować się inaczej niż w myśl zasady "zastaw się, a postaw się". Nocna zabawa jest idealną okazją do realizacji interesów, czyli przekonania pijanego dziadka do przekazania ziemi dla ukochanej wnuczki - panny młodej. Okazuje się, że znalezienie notariusza nie stanowi problemu, gdy otrzyma on podwójną zapłatę. Najistotniejsza jest jednak ludyczna zabawa przepełniona seksualnymi aluzjami współuczestników kiczowatej, chodź dla nich przepełnionej witalnością imprezy.

Trwa wesele, a poszczególne postaci wyłaniają się z wirującego w rytm disco polo korowodu, aby ubijać trefne interesy lub prowadzić rozmowy ujawniające ich przerażającą prymitywność (Giza, 2007, s. 107).

\section{Obraz ten jest oczywiście przerysowany. Według Barbary Gizy,}

Smarzowski dokonuje zabiegu, o którym pisał Franciszek Ziejka: próbuje osądzić świat współczesny za pomocą samej materii przedstawianych spraw. W ten sposób każdy odbiorca może dokonać indywidualnej "spowiedzi” i przeanalizować własną mentalność opanowaną przez stereotypy, fobie i mity (Giza, 2007, s. 107).

Karykaturalne sytuacje i parodystyczne elementy powracają w każdym filmie reżysera. Smarzowski, broniąc się, odpowiadał w "Kinie":

Pytania o przerysowania już padały, o ilość wypitego na planie alkoholu też. Przyzwyczaiłem się. Moim zdaniem pokazane w filmach sytuacje nie są przerysowane. Są jedynie skumulowane, zagęszczone (Śmiałkowski, 2009, s. 15). 
Wydaje się bowiem, iż wiele z sytuacji ukazanych w Weselu odnaleźlibyśmy na imprezach organizowanych nawet dziś. Zmieniło się wnętrze (nie jest to już remiza, a elegancki lokal), ale zachowania gości nie zawsze. Zatem oglądamy się w lustrze i śmiejemy sami z siebie. Trafnego porównania dokonuje Witold Mrozek, zauważając:

Zarówno Wesele Andrzeja Wajdy z 1972 roku, jak i film Wojciecha Smarzowskiego z roku 2004 mogą być przykładami kina narodowego, które w błyskawiczny i spójny sposób przedstawiają wady i zalety Polaków. Oczywiście próba ukazania charakteru narodowego na podstawie pewnej określonej grupy ludzi i interakcji w ograniczonym czasie zawsze w pewnym stopniu opierać się będzie na schematach (Mrozek, 2010, s. 323).

\section{CHARAKTER NARODOWY}

Druga kategoria to narodowe gusta. Tematyka charakteru narodowego od zawsze istnieje w życiu społecznym jako nieodłączny element kultury. Jako zjawisko społeczne jest związana z gustami, zwyczajami, religią czy przynależnością narodową, a więc jest wyznacznikiem tożsamości i ma znaczenie symboliczne. Smarzowski odnajduje kolejne elementy składające się na obraz stereotypowego Polaka. Poprzednia kategoria odbicia lustrzanego znana z narracji Nabukowa zarówno na poziomie historii, jak i dyskursu nawiązuje do narzędzi związanych z własną nieświadomością. Ona też pojawia się, gdy mówimy o narodowych gustach. W Pod Mocnym Aniołem Wojciech Smarzowski wykorzystuje technikę korkociągu. Wbija skręcony szpikulec w widza powodując, że ten wychodzi odrętwiały z kina. Sparaliżowanie okazuje się takim samym efektem, jak dolegliwości upojenia alkoholowego. Po raz kolejny reżyser sięga po temat alkoholu. Gdyby trzeba było określić rodzaj trunku, jaki pojawia się w jego filmach, bez wątpienia jest on tani i gorzki. Od Wesela po Dom zły, a kończąc na Drogówce bohaterowie stają w korowodzie postaci z kroniki upadków moralnych. Piją podczas rodzinnego święta, dokonywania zbrodni, w trakcie i po pracy. Na wsi i w mieście. Jakub Socha konstatuje:

Szarpana narracja, nerwowa muzyka, mieszanie struktur czasowych. Te same twarze, te same gesty, tylko że w jeszcze większym stężeniu. Ta sama wizja świata, tylko że jakby bardziej podkręcona. Dom zły to już zły świat, a ludzie? Ludzie to coś dużo gorszego niż wilki (Socha, 2014).

W Pod Mocnym Aniołem, będącym ekranizacją książki Jerzego Pilcha, mamy sytuację bezustannego wychodzenia z nałogu. Bycia w pętli nałogu, która w tym wypadku nie ma statusu społecznego. Profesor Maria Janion, wręczając nagrodę literacką NIKE 2001 Jerzemu Pilchowi, mówiła: „Po mistrzowsku gra z tradycją powieści pijackiej, dowodząc jak autokreacja alkoholika bliska jest opowiadaniu siebie przez pisarza" (redPor, 2013). Główny bohater filmu - Jerzy jest jednocześnie pisarzem i alkoholikiem. Zakochując się w atrakcyjnej kobiecie, ma nadzieję na szybki powrót do zdrowia, jednak uzależnienie okazuje się silniejsze niż uczucie, w wyniku czego trafia do ośrodka dla deliryków. Tam spotyka reprezentację narodowej spirytiady: robotnika, reżysera, kierowcę, fryzjerkę. Gdy poznają Jerzego, proponują mu rolę skryby opisującego ich alkoholowe historie. Wszyscy oni przebywają pomiędzy iluzją życia i ułudą nałogu. Idealnie oddają to sceny na korytarzu ośrodka, gdzie wielokrotnie widzimy ich obserwujących świat przez okno. Za chwilę mogą znaleźć się po jego drugiej stronie, choć my doskonale wiemy, że szybko wrócą na dywanik dyrektora. 
W Pętli Jerzego Hasa pada sformułowanie, że „wódka jest prawdą, którą rozumie się zbyt późno". Myśl ta wydaje się bliska Jerzemu z filmu Smarzowskiego, który pije, bo pije. Reżyser stosuje nielinearną narrację, powtarza w nieskończoność cykle tak, aby przywołać wrażenie pijackiego zwidu. Oglądamy bowiem świat oczami głównego bohatera, postaci, która nieustannie wymiotuje, bywa niechlujna i wulgarna. Przez jego mieszkanie przechodzi tajfun, coraz większy z każdą kolejną kupioną w sklepie butelką.

Nietrudno dostrzec, że Pod Mocnym Aniołem zarówno bardzo mocno wychodzi poza krąg czysto intelektualno-artystyczny, jak i wręcz topatologicznie uświadamia, że uzależnienie i jego konsekwencje nie są patologią właściwą społecznemu marginesowi (Michalska, 2014).

Pod Mocnym Aniotem wydaje się historią już opowiedzianą przez tego reżysera. Doprowadzoną do ekstremum poprzez zastosowanie wszechogarniającej brzydoty. Ekstremum goni ekstremum, nie dając widzowi wytchnienia, stawiając go pod ścianą. Smarzowski wymachuje stępioną siekierą, która nie potrafi już zdiagnozować polskiej mentalności. Bartosz Żurawiecki, recenzując film, podkreślał:

Alkoholizm to od wieków nasza narodowa choroba - powiada Smarzowski za autorem literackiego pierwowzoru, Jerzym Pilchem. By tego dowieść, film w pewnym momencie cofa się w czasie i pokazuje przodka głównego bohatera, który dla wódki gotów był zabić (Żurawiecki, 2014, ss. 74-75).

\section{PIERWIASTEK ETNICZNY}

Kolejnym z czynników budujących poczucie tożsamości narodowej jest pierwiastek etniczny. Członkowie owej grupy postrzegają historię jako źródło decydujące o przynależności. Ważnym elementem wpływającym na poczucie tożsamości narodowej jest wspólna organizacja polityczna. Ułatwia przekształcanie się zbiorowości w naród. To właśnie państwo wyznacza jednolite zasady współżycia i wspólne cele, gwarantując tym samym bezpieczeństwo, lepsze warunki rozwoju i możliwość wpływu mieszkańców na losy kraju. Witold Mrozek zaznacza:

Autostereotyp, którego obraz został ukształtowany w swej zasadniczej postaci w okresie ponad stuletniego braku własnej państwowości wyraźnie wskazuje na udział w tworzeniu się narodowej tożsamości. (...) Na ile kino historyczne jest kinem narodowym. Czy historyczne doświadczenie, które składają się na pewnego rodzaju mit założycielskich narodu polskiego przywołują tradycyjne obraz Polaka katolika i patrioty, mogą nadal być podstawą kina narodowego? (Żurawiecki, 2014, s. 324).

Refleksję dotyczącą narodowych mitów można odnaleźć w każdym z filmów Smarzowskiego. Znacząca jest jednak Róża, o której Tadeusz Sobolewski pisał: „Wyraża niewymowne cierpienie, szaleństwo historii, odsłania niekończący się łańcuch zła i gwałtu, na którym wyrosło pokojowe życie wschodniej Europy" (Sobolewski, 2012). Róża bowiem omawia wydarzenia po 1945 roku, kiedy rozpoczęła się akcja rejestracji i weryfikacji autochtonów Mazur i Warmii. Sytuacja ta spowodowała konflikt narodowościowy. Wielu mieszkańców tych ziem nie przyznało się do polskich korzeni, jak również odrzuciło polskie obywatelstwo. Profesor Stanisław Achremczyk konstatuje: 
Spotkanie z Polską było dla tej ludności gorzkie, szczególnie dla tych, którzy przed wojną dziatali $w$ ruchu polskim. Także kobiety, których mężowie byli w Niemczech lub w sowieckich obozach, nie chciały pod przymusem deklarować polskości. Takich spraw nie załatwia się dekretem, bo jest to dłuższy proces (Książek, 2012).

Główny bohater filmu - Tadeusz, którego żonę zgwałcili i zabili Niemcy, jest żołnierzem AK. Zdarzyło się to podczas powstania warszawskiego. Mężczyzna udaje się na teren Mazur, gdzie szuka schronienia. Trafia do gospodarstwa Róży Kwiatkowskiej, której mąż zginąt jako żołnierz Wermachtu. Kobieta wielokrotnie gwałcona, "w stanie walki z okolicznymi bandami maruderów", wreszcie otoczona ostracyzmem lokalnej społeczności, widzącej w niej rosyjską kurwę, zdaje się niewzruszona. Jej opór wobec propozycji pomocy zdaje się tym bardziej przerażający, że jak okazuje się w toku opowieści, kobieta nie tylko nie przestaje nadal potrzebować wsparcia, ale przede wszystkim jest świadoma jego potrzeby (Świrek, 2012, s. 81). Róża nie jest w stanie zatrzymać spirali zła, jaka ją otacza. "Gwałt nie zna granic, przychodzi jak fala, pobudzona przez wojnę". Smarzowski wykracza jednak poza ramy polityki historycznej. Jak zauważył Tadeusz Sobolewski, film Róża nie zaspokoi tych, którzy chcieliby zobaczyć w nim przede wszystkim obraz o polskich cierpieniach, ponieważ gwałt zadają również sami Polacy (Sobolewski, 2012). Nie tylko ściany mieszkania Róży są czarne, ale i wśród ludzi, którzy przyszli na te ziemie, wielu jest podłych i nikczemnych.

Róża naprawde jest różą, krwawiącym kwiatem jest jej ciało. (...) Wojciech Smarzowski dokonał narracyjnego przełomu zachowując męski punkt widzenia, który nie dominuje ani nie uprzedmiotowia kobiecej prawdy: widzimy krzywdę Róży, lecz nigdy jej biernie nie obserwujemy, bo kamera interweniuje wraz z Tadeuszem. Brutalne kino, a tyle delikatności (Jaworska, 2012, s. 69).

Zróżnicowana etnicznie ludność Warmii i Mazur skazana była na zawłaszczenia. Erwin Kruk konstatuje:

Warmia i Mazury były obszarem wielkich migracji i wymiany ludnościowej. Nie tylko konkretna polityka władz spychała miejscowych na margines. Z psychologicznych względów owo upokorzenie ludności autochtonicznej spotkało się z przyzwoleniem całych rzesz osadników (Kruk, 2003, s. 200).

Armia Czerwona nie zdążyła jeszcze opuścić okolicy, a już pojawili się pierwsi przedstawiciele nowej Polski. Słusznie zauważa Krzysztof Świrek, że:

poprzez problem Mazurów przyglądamy się drobnej części procesu, który w ciągu zaledwie kilku lat ograbił polskie społeczeństwo z wielkiego skarbu kulturowej i etnicznej różnorodności. Problem owej katastrofy, polegającej na uczynieniu z polskiego państwa etnicznego monolitu, nadal domaga się głębszego rozpoznania w kinie, a nie sprzyjała jego przeżyciu ani postawa władz komunistycznej Polski, chętnie używających nacjonalistycznego frazesu, ani rzeczywiste odrodzenie nacjonalizmu u schyłku poprzedniego stulecia (Świrek, 2012, s. 81).

Szacuje się, że po wojnie w latach 1946-1947 zostało na tych terenach ok. 100 tysięcy Mazurów. Michał Szczerbic, autor scenariusza Róży, który mieszka na Mazurach, przekonywał w wywiadzie dla olsztyńskiego pisma „Debata”, że zwykła powinność nakazywała mu napisać o Mazurach.

Wiedziałem od początku, że ten film może zrobić tylko Wojtek Smarzowski. Nasze poglądy długo się ucierały. Dzisiaj wiem, że powstał film wybitny (Jarosiński, 2012). 
Twórczość Wojciecha Smarzowskiego, z jednej strony, skonstatować można jako typowo narodową. Każdy z filmów dotyczy polskiej historii lub współczesności, dodatkowo dzieją się na terenach kraju i opowiadają o tematach bliskich Polakom. Z drugiej jednak strony reżyser bardzo krytycznie spogląda na obecną i zaszłą rzeczywistość, prowadzi zbiorową psychoanalizę narodu, zaczyna od komedii a kończy na thrillerze. Dostrzega problemy, o których inni chcieliby zapomnieć, albo postaci, o których należy milczeć. Dzięki temu wywołuje w widzu skrajne emocje, począwszy na śmiechu, a skończywszy na złości. Smarzowski wyróżnia się na tle innych polskich reżyserów ostatnich lat. Przygląda się transformacji ustrojowej i przemianie zwykłych obywateli w różnych momentach historii. Zastanawia się nad egzekwowaniem prawa, działalnością instytucji państwowych, urzędników i duchownych. Za każdym razem zmieniają się okoliczności, a mechanizm pozostaje ten sam. Czy Drogówka rozgrywająca się w stolicy, Wesele w centralnej Polsce, czy Dom zły w Bieszczadach zasada jest prosta. Każdy chce osiągnąć jak najwięcej dla siebie, jak najprostszymi metodami,a następnie dobrze się bawić w towarzystwie alkoholu. „Alkohol jest motorem akcji, skłania bohaterów do coraz bardziej ekstremalnych zachowań. Ściąga maski i znosi normy społeczne. Wyostrza narodowe stereotypy, z Polakiem alkoholikiem na czele. Upijając bohaterów, Smarzowski wyśmiewa polskie przywary" (Piepiórka, 2012, s. 18). Demaskatorska krytyka różnych grup społecznych sprowadza się również do analizy poszczególnych typów postaci, plejady „czarnych" charakterów polskiej rzeczywistości.

Polska nurza się u niego w gnojówce i błocie. Podobnie jak narodowe ikony. Rota zostaje wykonana nad ranem przez pijanych w trupa weselników, a hasło "Solidarności” wykrzyczane przez ludzi stojących w kolejce po wódkę, aby przegonić ze sklepu milicjantów (Piepiórka, 2012, s. 19).

Sytuacja jednak wciąż się zmienia, zauważył to Smarzowski w rozmowie z "Rzeczpospolitą":

Powiedzmy, że ten okres transformacji trwa trochę dłużej, niż zakładaliśmy. Ale na polskich ulicach widać mniej pijaków. Zastępują ich faceci w garniakach, którzy czekają do piątku, żeby dać w palnik. Z powodu prostego lęku o byt ci panowie nie przychodzą do pracy narąbani (Brzywczy, 2013).

Zmienia się obyczajowość, nie zmienia się zamiłowanie do kieliszka. Pije elegancka pani i zarośnięty facet pod budką. Dlatego kolejny film, który właśnie trafił do kin, dotyczy uzależnienia od alkoholu. W Pod Mocnym Aniołem znowu nadmiar realizmu, wulgarność i brzydota. Zainicjowane na początku kariery zamiłowanie reżysera do opowiadania, jacy jesteśmy, nie mija.

Twórczość Smarzowskiego niepokoi. Mimo nierealistycznego nadmiaru i groteskowej deformacji, jest głęboko zakorzeniona w rzeczywistości, będąc w istocie krytyką naszego społeczeństwa (Piepiórka, 2012, s. 19).

Wydaje się, że ciągle oglądamy ten sam film, ale może tacy właśnie jesteśmy.

Kategorie odbicia lustrzanego, narodowych gustów i pierwiastka etnicznego wpisują się w całą twórczość Wojciecha Smarzowskiego. Każde dzieło reżysera, pomimo innej tematyki, dotyka pojęcia tożsamości narodowej. Autor zastanawia się nad pamięcią drugiej wojny światowej, czasów komunistycznych i okresu po transformacji. Wyłania się obraz niespełnionych romantycznych pragnień, budowania mitów czy stereotypów. Smarzow- 
ski dokonuje dekonstrukcji, obalając wszystkie dotychczasowe obrazy polskiej historii, bohaterstwa i symboli. Jego filmy mogą służyć jako źródło, element składowy pamięci społecznej. Smarzowski w rozmowie o polskiej tożsamości konstatuje:

Z ojczyzną to jest tak jak z rodzicami, kochasz ich i już. Dopiero czas, książki, filmy, podróże, konfrontacja z inną mentalnością czy szereg innych bodźców powoduje, że od czasu do czasu sobie takie pytanie zadajemy. Ja sobie w każdym razie zadaję i moja odpowiedź: lubię Polskę (Pietrasik, 2009, s. 47).

Reżyser dokonuje rozrachunku z polskością, dlatego należy go nazwać twórcą narodowym. Jednocześnie analizowane dzieła uzmysławiają niezwykłą istotność kategorii tożsamości narodowej determinującej dzieje, zachowania i odbiór całego społeczeństwa. Smarzowski prowokuje do krytycznej refleksji o nas samych jako więźniach zbiorowej tożsamości.

\section{BIBLIOGRAFIA}

Brzywczy, M. (2013, luty 3). Smarzowski w krainie Simpsonów. Przekrój. Pobrano 16 grudnia 2015, z http://beta.rp.pl/http://www.przekroj.pl/artykul/976670-Smarzowski -w-krainie-Simpsonow.html

Giza, B. (2007). Wyspiański - Wajda - Smarzowski. Sto lat „Wesela”. W P. Zwierzchowski \& D. Mazur (Red.), Kino polskie wczoraj i dziś: kino polskie po roku 1989. Bydgoszcz: Wydawnictwo UKW.

Higson, A. (2008). Ograniczona wyobraźnia kina narodowego. Kwartalnik filmowy, 62-63. Jarosiński, D. (2012, luty 1). „Róża”. Film, który zakłócił spokój. Debata. Pobrano 16 grudnia 2015, z http://www.debata.olsztyn.pl/index.php?option=com_ content\&view=article\&id=2068:qroa-film-ktory-zakoci-spokoj\&catid=65: publicystyka\&l temid $=123$

Jaworska, J. (2012). Róża i krew. Dialog, 7-8.

Kłoskowska, A. (2007). Socjologia kultury. Warszawa: Wydawnictwo Naukowe PWN.

Kruk, E. (2003). Warmia i Mazury. Wrocław: Wydawnictwo Dolnośląskie.

Książek, M. (2012, luty 5). Przerwane dziedzictwo Mazurów. Przegląd. Pobrano 16 grudnia 2015, z http://www.tygodnikprzeglad.pl/przerwane-dziedzictwo-mazurow/

Lacan, J. (1996). Funkcja i pole mówienia i mowy w psychoanalizie. Warszawa: Wydawnictwo KR .

Lubelski, T. (2010). Historia Kina Polskiego. Twórcy, Filmy, Konteksty. Warszawa: Videograf II.

Michalska, M. (2014). Serca alkoholowe. Kultura Liberalna, 263(4).

Mrozek, W. (2010). Film pamięci narodowej. Najnowsze kino polskie w dyskursie polityki historycznej. W T. Lubelski \& M. Stroiński. (Red.), Kino polskie jako kino narodowe. Kraków: Korporacja ha!art.

Piepiórka, M. (2012). Świat zły, czyli kino Wojciecha Smarzowskiego. Kino, (2).

Pietrasik, Z. (2009, listopad 4). Smarzowski: Na weselach nie tańczę. Polityka. Pobrano 16 grudnia 2015, z http://www.polityka.pl/tygodnikpolityka/paszporty/12387,1,rozmowa -z-wojciechem-smarzowskim.read

redPor. (2013, wrzesień 30). Warto czytać książki - NIKE dla Pilcha. Gazeta Wyborcza. Pobrano 16 grudnia 2015, z http://wyborcza.pl/1,81850,983694.html 
Sobolewski, T. (2012, luty 2). Wybitny film „Róża”. Pole minowe historii. Gazeta Wyborcza. Pobrano 16 grudnia 2015, z http://wyborcza.pl/1,75475,11073235,Wybitny_film_ Roza__Pole_minowe_historii.html

Socha, J. (2014). Po pierwsze: nie pij. Dwutygodnik.com. Pobrano 16 grudnia 2015, z http://www.dwutygodnik.com/artykul/5001-po-pierwsze-nie-pij.html

Śmiałkowski, P. (2009). Do czego zdolny jest człowiek, Kino, (9).

Świrek, K. (2012). Róża. Kino, (2).

Żurawiecki, B. (2014). Pod Mocnym Aniołem. Kino, (1). 